Science of The Total Environment

February 2019, Volume 651 Issue Part.1 Pages 1-11

http://dx.doi.org/10.1016/i.scitotenv.2018.09.139

http://archimer.ifremer.fr/doc/00456/56734/

(c) 2018 Published by Elsevier B.V.

\title{
Eutrophication: A new wine in an old bottle?
}

\author{
Le Moal Morgane 1, 2, 3, 4, 5, 6, 7,8, Gascuel-Odoux Chantal ${ }^{2}$, Ménesguen Alain ${ }^{3}$, Souchon Yves ${ }^{4}$, \\ Étrillard Claire ${ }^{5}$, Levain Alix ${ }^{6}$, Moatar Florentina ${ }^{4,7}$, Pannard Alexandrine ${ }^{8}$, Souchu Philippe ${ }^{9}$, \\ Lefebvre Alain ${ }^{10}$, Pinay Gilles ${ }^{1,4,8,{ }^{*}}$
}

${ }^{1}$ CNRS, OSUR, Rennes, France

2 Inra, Agrocampus Ouest, UMR SAS, Rennes, France

3 Ifremer, Laboratoire d'écologie Benthique côtière, Brest, France

${ }^{4}$ Irstea, UR RiverLy, Lyon, France

${ }^{5}$ Inra, Agrocampus Ouest, UMR SMART, Rennes, France

${ }^{6}$ Inra, UMR Lisis, Marne-La-Vallée, France

${ }^{7}$ University of Tours, GEHCO, Tours, France

${ }^{8}$ University of Rennes, Ecobio, CNRS, Rennes, France

${ }^{9}$ Ifremer, Laboratoire Environnement Ressources, Nantes, France

${ }^{10}$ Ifremer, Laboratoire Environnement Ressources, Boulogne sur Mer, France

* Corresponding author : Gilles Pinay, email address : gilles.pinay@irstea.fr

\begin{abstract}
:
Eutrophication is one of the most common causes of water quality impairment of inland and marine waters. Its best-known manifestations are toxic cyanobacteria blooms in lakes and waterways and proliferations of green macro algae in coastal areas. The term eutrophication is used by both the scientific community and public policy-makers, and therefore has a myriad of definitions. The introduction by the public authorities of regulations to limit eutrophication is a source of tension and debate on the activities identified as contributing or having contributed decisively to these phenomena. Debates on the identification of the driving factors and risk levels of eutrophication, seeking to guide public policies, have led the ministries in charge of the environment and agriculture to ask for a joint scientific appraisal to be conducted on the subject. Four French research institutes were mandated to produce a critical scientific analysis on the latest knowledge of the causes, mechanisms, consequences and predictability of eutrophication phenomena. This paper provides the methodology and the main findings of this two years exercise involving 40 scientific experts.
\end{abstract}




\section{Graphical abstract}

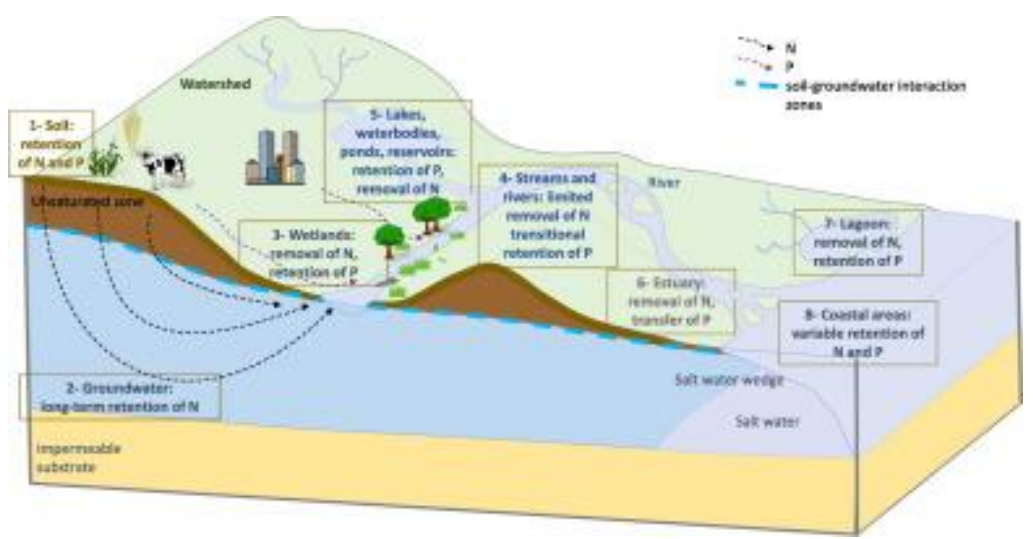

\section{Highlights}

Eutrophication in the 70ies was related to point source pollution, mainly phosphorus. Eutrophication is pervasive in many lakes, coastal areas and rivers of the world. Diffuse nitrogen and phosphorus losses are now the main drivers of this new wave of eutrophication. $>$ It is a wicked problem as a consequence of multiple, often cumulative actions other large spatio-temporal scales. Solutions to tackle eutrophication need to address the entire land-sea continuum.

Keywords : Eutrophication, Nitrogen, Phosphorus, Algae bloom, Land-sea continuum, Diffuse pollution 


\section{$28 \quad$ Introduction}

29

Eutrophication is one of the most common causes of water quality impairment of inland and

30 marine waters (Vitousek et al., 1997; Smith et al., 1999; Bennett et al., 2001; de Jonge et al., 2002;

31 Smith, 2003). It is generating major disruptions to aquatic ecosystems and has impacts on related 
goods and services, on human health and on the economic activities of the territories where they occur. A large amount of research has been conducted during the 1970ies and 80ies to understand the causes and mechanisms underlying the process of eutrophication which was spreading in the Northern Hemisphere's lakes (Vollenweider, 1970; Schindler, 1974 ; Dillon and Rigler, 1974 ; Hecky and Kilham, 1988). These researches clearly pointed out the key role of phosphorus point source pollutions and spectacular recoveries, at least at the time, were monitored following a reduction of point source phosphorus pollution.

Yet, today eutrophication is pervasive in many lakes, coastal areas and rivers of the World. In some areas, these environmental crises have become an urgent societal issue, involving a wide variety of stakeholders with contrasting values and interests (Rabalais et al., 2002, Smetacek and Zingone, 2013). Diffuse nitrogen and phosphorus pollutions are now the main drivers of this new wave of eutrophication (Beusen et al., 2016). We argue with this diffuse context of nutrient pollution that this new eutrophication crisis can be considered as a "new wine in an old bottle". We consider that it is an "old bottle" because the consequences, i.e. algal bloom, anoxia are similar as those encountered in the 1970ies and 80ies. Yet, this is a "new wine" because this diffuse propagation forces to address: i) the long term cumulative impact of far reach anthropogenic activities, ii) the consequences of multiple, and often cumulative, actions which can be very distant both in space and time, iii) the difficulty to disentangle past and present causes from past anthropogenic legacy. The consequence of multiple, often cumulative actions, which can be very remote both in space and time from the visible impact, the uniqueness of each aquatic ecosystem, its resistance, resilience and trajectory, the difficulty to disentangle past and present causes from legacy of the past anthropogenic activities fulfil many attributes of a wicked or complex problem facing society (Thornton et al., 2013). Indeed, there is no single answer applicable to resolving eutrophication, no true-false answers, and there is no end point in implementing a solution. Moreover, there is no a priori understanding of the outcomes associated with interventions intended to solve eutrophication. Furthermore, the application of one intervention to resolve a specific case of eutrophication may have a different outcome when applied to a similar problem in a different location. Yet, the planner has no right to be wrong (Thornton et al., 2013). The development of eutrophication exemplifies the linkages between physical and biogeochemical 
processes along the land-sea continuum. However, from headwater catchments to coast areas, several often antagonistic interests prevail, while scientists are often specialized in one domain, with limited interactions and shared methods, tools or models. There is a need for interdisciplinary approach calling for several disciplines of agronomy, engineering, biogeochemistry, ecology, hydrology, economy, political sciences and sociology to provide ways and approaches for aquatic ecosystems remediation from this world-wide and pervasive problem of eutrophication.

This manuscript brings together the reviews undertaken by a set of French scientists who were requested from the French ministries in charge of environment and agriculture to provide the state-ofthe-art on eutrophication. The following papers of the special issue on "eutrophication: a new wine in an old bottle" gather interdisciplinary research on eutrophication with special emphasis on land-water interactions along the land-water-sea continuum.

\section{Method}

The joint scientific appraisal is an institutional, scientific and collective expertise. It consists in collating the international scientific literature on a given topic and extracting points of certainty and uncertainty, knowledge gaps and any questions that are the subject of scientific controversy. The purpose of a joint scientific appraisal is to provide the public authorities and all the stakeholders with a base of certified scientific knowledge on which to build a political science-based decision-making process. This state of knowledge is not intended to provide expert advice or turnkey technical solutions to the issues faced by administrators, but to identify levers for action.

A national appraisal charter signed by the CNRS (National Center for Scientific Research), Ifremer (French institute of Marine Research), Inra (National Research Institute of Agronomy) and Irstea (Institute of Research and Development on Environment and Agriculture) governed this joint scientific appraisal. A multidisciplinary group of expert researchers from various backgrounds has conducted this appraisal on eutrophication. 40 French and foreign experts were mobilized, with skills in the following disciplines: ecology, hydrology, biogeochemistry, biotechnical sciences, social sciences, law, economics, and covering the various types of aquatic ecosystems: lakes, streams, estuaries, marine coastal and offshore environment, as well as the concept of continuum between these 
systems. The experts' work drew on a bibliographic corpus selected from the Web of Science of around 4,000 references, composed of scientific articles validated by peers, and supplemented, for a number of topics, by technical or scientific reports and legal texts. The full report is freely accessible on the following site (http://www.chrs.fr/inee/communication/breves/eutrophisation.html).

\section{What is eutrophication and why and how does it occur?}

\section{Definition of eutrophication}

The term "eutrophication" is used in the scientific literature to refer to a natural process of increased production of organic materials (Rabalais et al., 2004), accompanying the evolution of an aquatic ecosystem over geologic time, until eventually it fills up completely. It can also refer to a process resulting from anthropogenic activities on short time scales (hours, days, months, years). Anthropogenic eutrophication, in its proposed definition based on an analysis of the literature, refers to the overproduction of organic material induced by anthropogenic inputs of phosphorus and nitrogen (Smith et al., 1999; Andersen et al., 2006). Although similar in terms of mechanisms, these two definitions involve processes that do not occur on the same time scales, and therefore have totally different ecological and societal effects. Anthropogenic eutrophication is the focus of societal concerns and is the subject of this joint scientific appraisal. In this definition, the concept of syndrome, which is defined as a set of symptoms, is used to overcome the difficulty of summarizing in a few words the multitude of biogeochemical and biological responses (also called direct and indirect effects) triggered by nitrogen and phosphorus inputs underlined by different authors such as Carpenter et al. (1998).

What are the key factors and the mechanisms responsible for eutrophication?

The functioning of aquatic ecosystems is governed by dynamic balances. Eutrophication is an imbalance in functioning, triggered by a change in the quantity, relative proportions or chemical forms of nitrogen and phosphorus entering aquatic systems. The nature and intensity of responses also depends on environmental factors: long water residence times, high temperatures and a sufficient amount of light all stimulate eutrophication. Both continental and marine water ecosystems share the 
same general response mechanism to changes in nutrient flows (Fig. 1) (Claussen et al., 2009): an increase in nutrient inputs causes an increase in plant biomass, gradually generating a decrease in light penetration in the water column. Aquatic ecosystems thus shift from a system with limited nutrient inputs to a system gradually saturated in nutrients, in which light becomes the new limiting factor.

What are the manifestations of eutrophication?

Proliferations of opportunistic plant species, adapted to these new environmental conditions, replace the species initially present, inducing changes in the structure and functioning of all the communities (phytoplankton, zooplankton, benthic fauna, fish, etc.). These proliferations, or blooms, produce large biomasses. Their degradation by bacteria results in oxygen depletion in the aquatic environment (hypoxia or anoxia), or even toxic emissions $\left(\mathrm{CO}_{2}, \mathrm{H}_{2} \mathrm{~S}\right.$ and $\left.\mathrm{CH}_{4}\right)$. Some of these proliferations may be toxic. Responses generated by such a disturbance are initially detectable at the physiological/biochemical level of an individual, then at behavioural or morphological levels, and finally at the levels of the populations and communities. The most notable effects of eutrophication are vegetal blooms, sometimes toxic, loss of biodiversity and anoxia, which can lead to the massive death of aquatic organisms. In the bays of large river systems and some lakes, water chestnut (Trapa natans), or water ferns such as Azolla sp., for example, have proliferated to the extent of causing hypoxia and anoxia in the environment. In lakes, cyanobacteria all include species capable of producing toxins. They belong to the Microcystis, Planktothrix, Dolichospermum, Aphanizomenon, Oscillatoria, Lyngbya, Nodularia genera. In coastal environments, the decomposition of opportunistic green macroalgae blooms, mainly of the Ulva genus, results in hypoxia and anoxia, causing mass mortality of benthic fauna, a regression of fish nursery areas and health risks through the release of hydrogen sulphide. Excessive proliferation of phytoplankton in coastal seas also causes hypoxia or even anoxia in bottom waters (e.g. Gulf of Mexico, Chesapeake Bay, and Baltic Sea). Finally, marine eutrophication can stimulate Harmful Algal Blooms with (i) production of phytoplanktonic toxins, for instance in species of the Alexandrium, Dinophysis and Pseudo-nitzschia genera and/or (ii) production of high biomass with foam accumulation by Phaeocystis globosa, for example . 
What are the environmental, economic and social impacts?

Eutrophication poses a threat to the environment, the economy (e.g. impact on shellfish production, fishing, tourism), but also to human health (Von Blottnitz et al., 2006; Sutton et al., 2011). Attempts to evaluate the monetary impacts of eutrophication have been made over the last two decades, mainly in the United States and in the Baltic Sea (Dodds et al., 2008; Gren et al., 1997). These studies indicate a variety of impacts and costs which are quantifiable fairly directly, for instance when cities of hundreds of thousands of people are deprived of drinking water for several days. One example is the toxic algal bloom in the western Lake Erie basin in 2014, which led to disruption of water supplies to 400,000 people (Smith et al., 2015) On the other hand, integrating all the environmental, health and socio-economic impacts in the calculations of indirect effects, poses more of a challenge (Folke et al., 1994; Romstad, 2014).

\section{What criteria can be used to characterize eutrophication?}

Indicators of eutrophication are generally classified into indicators of pressure, chemical status and impact (Table 1). Pressure and status indicators relate respectively to the identification and quantification of pollutant sources, their loads and concentrations, whereas the impact indicators use the biological responses of the living communities specific to each type of environment. Some indicators have been provided by different authors (e.g. Friberg, 2014, for lotic systems; Ferreira et al., 2011, for seawater). These indicators can be used to link emissions and flows exported by watersheds with the concentrations measured in receiving environments and the biological or ecological status of these environments. While the Marine Strategy Framework Directive has settled on a Descriptor 5 dedicated to eutrophication to contribute to the Good Environmental Status assessment (MSFD, 2008, 2017), the Water Framework Directive opted instead for an aggregate vision of the Good Ecological Status of water bodies as a result of multiple pressures (WFD, 2000). The pressures responsible for eutrophication are partly documented in these directives (e.g. nutrient concentrations), but non-linear relations with ecological status often require more in-depth analysis in a number of regions. The interpretation of biological data (macrophytes, phytobenthos, invertebrates, and fish) is complex, 
contained within information on the integrated response of hydrosystems to multiple pressures, and dependent on adapted monitoring methods (frequency, accuracy).

\section{How is eutrophication changing over decades?}

Increasing global population growth and the development of urban concentration, agricultural industrialization and specialization of agriculture per region, including crop-livestock decoupling by means of animal feed transport, phosphorus mining and chemical manufacturing process of mineral nitrogen (Haber-Bosch method) have led to an increase in loads and concentrations of nutrients in terrestrial environment, and ultimately in aquatic ecosystems (Smith and Schindler, 2009). Estimation of changes in loads varies from one publication to another based on the approach, the scale and the databases used (Moatar and Meybeck, 2005). Many historical analyses have been performed (Howarth, 2008; Chen et al., 2016; Lu and Tian, 2017; Minaudo et al., 2015; Floury et al., 2017). Based on the latest models deployed globally, outflows to the sea doubled during the 20th century, from 34 to $64 \mathrm{Tg} \mathrm{N}$ per annum for nitrogen and from 5 to $9 \mathrm{Tg} \mathrm{P}$ per annum for phosphorus. The contribution of agriculture to these outputs has increased from $20 \%$ to $50 \%$ for nitrogen, and from $35 \%$ to 55\% for phosphorus (Beusen et al., 2016). In industrial countries, agricultural sources are now dominant, higher for nitrogen than for phosphorus (Dupas et al., 2015, Garnier et al., 2015). Eutrophication phenomena started to be recognized from the beginning of the 20th century near major urban and industrial centres in industrialized countries of the northern hemisphere.

Between the 1970s and 1990s, public action in these countries focused on the treatment of industrial and domestic pollution. The drastic reduction in point-source phosphorus pollution as a result of improving wastewater treatment, then banning phosphates in detergents, led to a gradual decrease in a number of eutrophication phenomena, notably in Lake Erie (United States) and Lake Geneva (FranceSwiss) (Anneville et al., 2002).

Since then, a new wave of eutrophication has been spreading, affecting many lakes, reservoirs, rivers and coastal areas around the world. Many iconic places are now subject to recurring eutrophication episodes and literature review: the Baltic Sea (Andersen et al., 2017), the Laurentian 

never been affected before, while others experienced a new eutrophication phenomenon after a previous remission phase (Jarvie et al., 2017). Since the end of the 20th century, public action has been focusing on the issue of agricultural non-point pollution. In industrialized countries, these measures have led to positive developments in freshwater, more so for phosphorus than for nitrogen, while marine eutrophication phenomena do not appear to have diminished since the beginning of the 21st century (Conley et al., 2009a). At global level, the number and footprint of hypoxic and anoxic zones in the marine environment has tripled since the 1960s (Diaz and Rosenberg, 2008). A 2010 census numbered nearly 500 of these areas, with a geographical footprint of $245,000 \mathrm{~km}^{2}$. There has also been an increase in the diversity, frequency, size and geographical extent of Harmful Algal Blooms in recent decades. Although it is still difficult to extrapolate trends from one region to another, the link between the increase in nutrients inputs and that of toxic blooms is often established.

Can the risk of eutrophication be characterized and predicted?

An analysis of the literature stresses that a risk analysis framework should combine hydrobiogeochemical transfers and transformations, climate hazards and the ecological vulnerability of receiving systems. These three dimensions are more or less integrated in modelling to better characterize risk and resilience of water bodies.

Transfer, retention and transformation of nitrogen and phosphorus along the land-sea continuum

The risk of eutrophication in an aquatic ecosystem depends partly on nutrient inputs from its watershed via the water pathways or groundwater inflows. Nutrient inputs can therefore come from source areas hundreds or even thousands of kilometres away, and their transit time from these areas to the receiving aquatic ecosystems can span decades (Pinay et al., 2015). Along the land-sea continuum, phosphorus is mainly retained in soils and sediments (Withers and Jarvie, 2008; Jarvie et al., 2013a, Jarvie et al., 2013b) (Fig. 2). Phosphorus can be remobilized depending on biological demand, under anoxic conditions, or when sediments are shifted. The entire 
phosphorus cycle is in solid or liquid form, while the nitrogen cycle has also a gas phase. Nitrogen is more mobile than phosphorus and is transported mainly as a dissolved form of nitrate directly to surface and also to groundwater, where it can be stored for decades (Molenat et al., 2013; Kolbe et al., 2016) (Fig. 2). In groundwater, wetlands and lake sediments, nitrates can, to a certain extent, be transformed into gaseous nitrogen by denitrification (biogeochemical processes). In soils and sediments, storage of the phosphorus introduced for more than a century by human activity has resulted in there being an excess of phosphorus (Delmas et al., 2013) in relation to nitrogen, although nitrogen can also be stored for decades in soils (Sébilo et al., 2013). Differences in biogeochemical processes controlling the cycling and transfers of $\mathrm{N}$ and $\mathrm{P}$ along the land-sea continuum can result in marked changes in nutrient stoichiometry from headwater catchments to the sea (Alexander et al., 2000).

These findings also explain why assessments of the retention capacity of phosphorus and of the elimination capacity of nitrogen in a watershed are currently difficult to make and highly uncertain. There is a great variability of flows in headwater catchments, and it has not been possible yet to establish a clear relation between landscape structures and agricultural practices, and the water quality of the draining rivers (Abbott et al., 2017). While the assessment can be performed with the help of a significant amount of equipment and measures, it remains difficult to quantify their effect in all real landscape configurations. Biogeochemical rates measured at one site cannot be extrapolated to other sites due to the specific hydrological, hydrogeomorphological and biogeochemical settings of each site (Bishop et al., 2008). This creates great spatial and temporal variability in denitrification and phosphorus retention.

\section{Taking account of climate change}

The effects of climate change, some of which are already felt, will impact all the mechanisms involved in eutrophication and amplify its symptoms (Moss et al., 2011; Paerl et al., 2014; Woznicki et al., 2016). Plant biomass production, transfers within watersheds, nutrient loads reaching hydrosystems, the physical chemistry of environments, especially oxygen, $\mathrm{pH}$ and discharges of phosphorus and metals from benthic sediments, the metabolization of nutrients in aquatic 
environments, organisms' habitats and their distribution, the dynamics of trophic networks; all of these processes are likely to be modified by forecast climate changes (changes in thermal and water regimes) as well as their interaction with related changes in human activity and terrestrial landscapes (Jeppesen et al., 2014). In turn, the benthic physico-chemical reactions involved in hypoxia are likely to contribute to the emission of greenhouse gases $\left(\mathrm{CO}_{2}, \mathrm{CH}_{4}\right.$, and $\left.\mathrm{N}_{2} \mathrm{O}\right)$. The literature is starting to propose distributed scenarios of future developments by changing the forcing factors of eutrophication risk analyses (Skogen et al., 2014). This is an essential step in guiding adaptation actions and scaling efforts to combat eutrophication.

\section{The vulnerability of ecosystems to eutrophication}

Each ecosystem is unique and has its own history and dynamics, which in turn are related to local geological, geomorphological, hydrological, ecological and climatic conditions, but also to past and present anthropogenic pressures and their nature, as well as to the sociological and economic contexts in which they have evolved. For instance, there are many possible responses of aquatic ecosystems under constraints of changes in nutrient inputs (Scheffer et al., 2001; Duarte et al., 2009). This complexity means that if general transfer and time-response can be predicted, the ecological vulnerability of ecosystems is still highly unpredictable (Fig.3). Vulnerability therefore needs to be defined by taking into account the entire direct and indirect causal chains that influences the inherent properties of the receiving aquatic ecosystems, in relation to the diversity of local situations and past and present contexts. Biological indicators are invaluable to reveal aggregated structural and functional degradations of waterbodies health, especially when they are conceived as multi metric indices, as requested in legislations like the USA Clean Water Act or European Union Water Framework Directive. Yet, these indicators are too global to build a risk analysis taking into account the ecological vulnerability to eutrophication. There is a need to adapt them to provide specific response to gradients of nutrients, and especially to tipping biological points versus nutrient concentrations. 
Modelling: a tool for understanding and predicting the evolution of aquatic ecosystems

Mathematical models of eutrophic ecosystems have been developed to understand and represent ecological dynamics and their coupling with nutrients (Cugier et al., 2005; Troost et al., 2013; Turner et al., 2006). Some models have also been used to estimate eutrophication risks, assess the necessary reduction in nutrient inputs and define actions and priority management areas. A first approach is based on the identification and combination of factors of nutrient emissions to aquatic ecosystems. Multi-criteria assessment of the impacts of technical systems (agricultural systems, wastewater treatment) based on life cycle analysis (Balkema et al., 2002) or nitrogen footprint (Doney, 2010) are also used to predict the consequences of human activities on aquatic ecosystems.. A second approach is based on statistical models (Allan et al., 2012), and aims at providing descriptors of eutrophication based on a number of causal variables. A third approach uses equations to represent hydro-biogeochemical and ecological mechanisms and simulates the dynamics of eutrophication (Almroth and Skogen, 2010). Most of the models combine these three approaches, depending on the availability of data on a given area.

Lake modelling focuses more particularly on the phosphorus cycle in order to remedy blooms of atmospheric dinitrogen-fixing cyanobacteria, because phosphorus is more easily removed from waste water (Jørgensen and Bendoricchio, 2001; Carpenter et al., 1999). Since 2000's however, models focus more and more on multiple nutrient cycles (Jørgensen, 2010). Due to the observed stimulation of non-dinitrogen-fixing cyanobacteria, lake modelling could be similar to that of rivers and coastal waters, which simulates $\mathrm{N}$ and $\mathrm{P}$ cycles in parallel. Marine eutrophication models identify nitrogen as a main controlling factor and recommend significant reductions in nitrogen river inputs (Chapelle et al., 2000). The transmission of this downstream ecological constraint to river system and watershed models founders on the lack of knowledge about storage compartments (groundwater for N, soil and sediment for $\mathrm{P}$ ) and their residence times, as well as the geographical complexity of land uses and watershed activities (Billen et al., 1991).

Models are commonly used to assess prospective scenarios. That said, replicability remains limited without substantial data on the zone under study, and the uncertainty of the results often receives little evaluation (Udovyk and Gilek, 2013; Durand et al., 2015). Very few examples integrate 
coupling with climate hazard and the ecological vulnerability of aquatic environments. The few bio-

economic models make it even more difficult to use modelling approaches to help towards remediation (Cellina et al., 2003). Nevertheless, modelling has made it possible to identify gaps in the processes understanding and representation that are still insufficiently detailed, in the data necessary for their implementation, and it has undoubtedly highlighted significant elements for reflection to guide management actions.

\section{What are the strategies and frameworks to combat eutrophication?}

\section{Engineering in aquatic ecosystems: a local solution}

Actions to combat eutrophication in aquatic ecosystems can build on three types of levers: physical levers, which are designed to decrease water residence time (Romo et al., 2013) or de-stratify the water column (Visser et al., 2016); chemical levers to fight hypoxia by artificially re-oxygenating the environment (Zamparas and Zacharias, 2014) or to help phosphorus precipitation (e.g. addition of lime or calcite, aluminium salts); ecological levers which seek either the eradication of symptoms (use of algaecides), or bio-manipulation by introducing species to influence the food web structure (Paerl, 2018). These approaches are costly, and sometimes risky, but they can help regulate a symptom, on a case by case basis, in small spatial areas (Carpenter et al., 2006).

\section{Managing phosphorus and nitrogen sources and delivery from terrestrial environments}

Actions to control nutrient inputs from watersheds are essential (Conley, 1999; Jarvie et al., 2018). They must be set in a long-term perspective, in relation with the transfer, retention and elimination mechanisms of nutrients along the land-sea continuum. Long transit times partly explain the limited decrease observed in nitrogen loads, and to a lesser extent of phosphorus loads, to watershed outlets, despite the efforts made to reduce inputs for several years. A vast range of objective knowledge currently supports a consensus among scientists to limit nitrogen and phosphorus inputs to aquatic ecosystems, whether they are point-source or non-point source inputs, of urban, industrial or agricultural origin. Nutrients cycles are not isolated from each other. Measures taken to regulate one element have consequences on other elements, and ultimately on the ecological balance of systems. A 
joint reduction in $\mathrm{N}$ and $\mathrm{P}$ inputs is therefore essential to curb eutrophication along the land-sea continuum (Paerl, 2009; Pearl et al., 2016), even though schematically, the controlling factor highly debated in the scientific literature (Blomqvist et al., 2004; Conley et al., 2009a Conley et al., 2009b; Elser et al., 2007; Howarth and Marino, 2006; Schindler, 2012) globally shifts from phosphorus in freshwater to nitrogen in marine environments.

Concerning domestic and industrial sources (non-collective sanitation, collection network and waste water treatment), significant efforts have been made, but there is still room for improvement: reduction at source (household products, diets, etc.), better assessment of the volumes to be treated, especially in areas where the population fluctuates, ramping up of a number of small water treatment plants, specific treatments (e.g. urine/faeces, agro-industrial waste).

Nevertheless, the focus is now on agricultural sources, which are significant in developed countries (Withers et al., 2014): more local animal feeding, effluent recycling in regions with high animal density; management of fertilization, taking into account $\mathrm{N}$ and $\mathrm{P}$, reasoned by plot, by cropping system (crop and intercrop); preservation or restoration of landscapes, especially land-water interfaces (Schoumans et al., 2014, as a review for P). These different levers must be taken into account in current production systems. However, even if they are taken into account, this will not be enough in watersheds with highly vulnerable receiving aquatic ecosystems. Agricultural systems and land use must be strongly modified in these zones. Economically realistic and socially acceptable territorial projects, based on targets for very low leakage of nitrogen and phosphorus, will have to be put in place. Synergies between issues related to food, biodiversity, climate, efficiency and resource recycling could help.

\section{Are regulatory monitoring frameworks well adapted to monitor eutrophication?}

Several regulatory texts mention the eutrophication process. They are international, European or national in scope, and respond to sometimes different rationales. For instance in Europe, several guidelines on uses, dating back to the 1980s and providing a framework for a given field (e.g. the Nitrates Directive and the Urban Waste Water Directive, UWWD), coexist with directives with a more comprehensive objective such as the Water Framework Directive (WFD) and the Marine Strategy 
Framework Directive (MSFD) in the 2000s. The Nitrates Directive, which focuses on nitrates from agricultural sources, requires the definition and delineation of nitrate vulnerable zones. Nitrate Vulnerable Zones are the watershed areas which contribute runoff to water bodies that have, or are at risk of (a) concentration above the drinking water standards, or (b) eutrophication. The UWWD requires the collection, treatment and discharges of wastewater, with point source-specific emission standards, but no standards for the receiving environment. The WFD and the MSFD require the implementation of the measures necessary to maintain or achieve the objective of good ecological and environmental status respectively in water bodies, notably by a regular characterization of the health state of hydrosystems. With the exception of the MSFD, these directives provide no specific recommendations on eutrophication, which is considered as part of a set of potentially degrading pressures. Targeted monitoring is required to evaluate compliance with water quality or ecological standards.

The nitrate drinking water standard of $50 \mathrm{mg} \mathrm{NO} / \mathrm{L}$ of nitrates, frequently referred to in the regulations, is not adapted to protecting environments from the eutrophication process. Concentrations of 1 to $3 \mathrm{mg} \mathrm{NO}_{3} / \mathrm{L}$ are characteristic of zones with very low human pressure; some publications identify a tipping point at barely higher values in the case of early changes in the species composition of macrophytes (James et al. 2005 ). These scientifically informed values and their translation into policy targets are also part of larger and disputed choices in the context of a global movement of "ecologization" of public policies. Therefore, further and comparative analysis of the historical trajectory of the various value guidelines suggested over time, including the influence of governance systems and their territorial implementation would be instrumental. Transparency on the fundamentals associated with these values and the related social learning approach are not only essential to set threshold value ranges, but also to connect eutrophication management goals with meaningful and shared visions of long-term local development.

\section{Socio-economic support for remediation}

Economic studies helps identify incentive or regulatory instruments capable, individually or in suitable combinations, of assisting in decision-making (Hansen and Hansen, 2014; Laukkanen and 
Huhtala, 2008; Xepapadeas, 2011). Existing economic studies show that in many cases, excessively ambitious objectives are not achievable and have led to ineffective programmes, especially in relation to their cost (Ahlvik et al., 2014). Targeting instruments spatially distributed is usually more effective than applying generic measures on a broad scale; this raises the question of zoning and of the scale of its definition. Adaptive management, by updating objectives and tools and attempting experiments based on achievable objectives and on a suitable scale, appears the best approach to adopt (Pahl-Wostl, 2007).

Until now, eutrophication issues have generally received little attention from environmental sociologists. Most of research work on the topic has furthermore focused on a series of emblematic cases, such as Laurentian Great Lakes (Gould, 1993) and Chesapeake Bay (Paolisso, 1999) in North America and the Baltic and North Seas in Europe (e.g., De Jong, 2016). In France, the case of green tides is an exception: once eutrophication has gained social visibility it can be more easily studied (Bourblanc, 2014). The transformation to be implemented in this context is no longer solely perceived as merely biophysical. Sociological and political aspects are starting to be taken into account, calling for differentiated approaches depending on the socio-ecosystems and their different spatial scales, and integrating the issues of the various stakeholders in relation to eutrophication (Gould, 1993; Levain et al., 2015).

\section{Future areas of investigation}

\section{Developing methodologies for assessing eutrophication risk}

Constructing an analytical framework of eutrophication risk requires that hydro-

biogeochemical processes, climate and the ecological vulnerability of receiving water bodies are all taken into account. In this sense, the literature identifies various areas for improvement in order to fully leverage the data collected and complete it as necessary: (i) performing regular scientific syntheses (e.g. every 10 years) analyzing both physico-chemical and biological data in various geographical frameworks, from an integrative and functional perspective; (ii) guiding the acquisition of new data to develop modelling approaches, particularly in the continental area, defining and rolling out probabilistic analyses of eutrophication risk; (iii) intensifying data acquisition in poorly 
instrumented zones (e.g. headwater catchments, soils and sediments), by increasing the frequency or accuracy of measurements, by measuring variables currently not monitored (e.g. 24-hour cycles, $\mathrm{O}_{2}$ ) in order to better qualify the relations between pressures and impacts, as well as response times in various biophysical contexts; (iv) developing new ways of data acquisition (including data management and processing), notably derived from recent technologies (high frequency and real time, including remote sensing) and citizen science; (v) better exploiting the functional information provided by biological samples: some taxa or ecological properties could deliver more information on trophic disfunctioning. For instance, taxa's ecological traits could provide more information on eutrophication sensitivity than the current global indices based on community structure.

The respective role of climate and human activity in driving eutrophication is also a major research requirement. Modelling can contribute based on long term observations. Research on the ecological responses to eutrophication should be strengthened, with the ambition of clearly distinguishing the part related to eutrophication in multi-pressure environments, watershed landscapes and the temporal trajectories of the various nutrient regimes and their drivers such as climate change, technical innovations, economic conditions or regulation.

\section{Moving towards systemic research}

The current challenge we are now facing is that despite a similar effects of nutrients pollution on freshwater, coastal and marine aquatic systems, i.e. "the old bottle", we cannot use remediation methods applied during the 1970ies and 80ies phase because we are dealing with diffuse inputs of nutrients, i.e. the "new wine". Yet, we still lack of highly inclusive research at territorial level to meet the different management issues of headwater catchments, riparian corridors and coastal areas. Remediation of eutrophication should therefore strive towards systemic approaches integrating hydrosystems, agricultural and urban areas, and production, feeding and recycling practices. Generally, the issue of agricultural transition is closely related to that of eutrophication. Models combining the biophysical and economic aspects need to be developed. The relation between changes in eutrophication and changes in socio-ecosystems should also be better put into perspective, going beyond sector-related focuses such as those placed on agriculture in recent decades. Sharing 
knowledge can recreate bonds between social groups and business sectors which are currently set apart from each other. There needs to be a greater number and variety of interdisciplinary investigation sites (lakes, rivers, coastal areas) where biophysical and societal dynamics could be studied over the long term, and existing investigation sites should be perpetuated. Sociological studies of public and governance problems are also needed. Research must be carried out on the limits of sector-specific regulatory approaches in terms of effectiveness, enforceability and overlapping, with as a common guideline a better integration of the land-sea continuum and distinctive vulnerability of each type of environment.

\section{Acknowledgments}

This study has been funded by the ministries in charge of Environment and agriculture, and the French Agency for Biodiversity we deeply thank. We particularly thank Jeanne Boughaba (Ministry of Environment) and Romuald Berrebi (French Agency for Biodiversity) for their involvement in coordinating this study. All the experts which are not in the authors lists (i.e. pilote and copilote of this study) have a strong contribution to these work and we warmly thank them for their involment, i.e. Lynda Aissani, Pierre Anschutz, Carole Barthélemy, Fabrice Beline, Gudrun Bornette, Catherine Boutin, Magalie Bourblanc, Annie Chapelle, Christian Chauvin, Pascal Claquin, Alain Crave, Pascal Denoroy, Jean-Marcel Dorioz, Jean-Marc Douguet, Isabelle Doussan, Patrick Durand, Agathe Euzen, Didier Gascuel, Élisabeth Gross, Nicolas Hoepffner, Jean-François Humbert, Geneviève Lacroix, Olivier Le Pape, Jean-Marie Lescot, Laurence Miossec, Behzad Mostajir, Frédéric Rimet, Nadège Rossi, Sabine Sauvage, José-Miguel Sanchez-Perez, Jean-Philippe Terreaux, Philippe UsseglioPolatera, Brigitte Vinçon-Leite.

\section{References}

Abbott, B.W., Gruau, G., Zarnetske, J.P., Moatar, F., Barbe, L., Thomas, Z., Fovet, O., Kolbe, T., Gu, S., Pierson-Wickmann, A.C., Davy, P., Pinay, G., 2017. Structure and synchrony of water quality in headwater stream networks. Ecology Letters DOI: 10.1111/ele.12897. 
Ahlvik, L., Ekholm, P., Hyytiäinen, K., Pitkänen, H., 2014. An economic-ecological model to evaluate impacts of nutrient abatement in the Baltic Sea. Environmental modelling \& software 55, $164-175$

Alexander, R.B., Smith, R.A., Schwarz, G.E., 2000. Effect of stream channel size on the delivery of nitrogen to the Gulf of Mexico. Nature 403 (6771), 758-761.

Allan, J.D., Yuan, L.L., Black, P., Stockton, T., Davies, P.E., Magierowski, R.H., Read, S.M., 2012. Investigating the relationships between environmental stressors and stream condition using Bayesian belief networks. Freshwater Biology 57 (s1), 58-73.

Almroth, E., Skogen, M.D., 2010. A North Sea and Baltic Sea model ensemble eutrophication assessment. Ambio 39 (1), 59-69.

Andersen, J.H., Carstensen, J., Conley, D.J., Dromph, K., Fleming-Lehtinen, V., Gustafsson, B.G., Josefson, A.B., Norkko, A., Villnäs, A., Murray, C., 2017. Long-term temporal and spatial trends in eutrophication status of the Baltic Sea. Biological Reviews 92 (1), 135-149.

Andersen, J.H., Schlüter, L., Ærtebjerg, G., 2006. Coastal eutrophication: recent developments in definitions and implications for monitoring strategies. Journal of Plankton Research 28 (7), 621628.

Anneville, O., Ginot, V., Druart, J.C., Angeli, N., 2002. Long-term study (1974-1998) of seasonal changes in the phytoplankton in Lake Geneva: a multi-table approach. Journal of Plankton Research 24 (10), 993-1007.

Balkema, A.J., Heinz A. Preisig, H.A., Otterpohl, R., Lambert, F.J.D., 2002. Indicators for the sustainability assessment of wastewater treatment systems. Urban Water 4, 153-161.

Barausse, A., Duci, A., Mazzoldi, C., Artioli, Y., Palmeri, L., 2009. Trophic network model of the Northern Adriatic Sea: analysis of an exploited and eutrophic ecosystem. Estuarine, Coastal and Shelf Science 83 (4), 577-590.

Bennett, E.M., Carpenter, S.R., Caraco, N.F., 2001. Human impact on erodable phosphorus and eutrophication: A global perspective: Increasing accumulation of phosphorus in soil threatens rivers, lakes, and coastal oceans with eutrophication. AIBS Bulletin 51 (3), 227-234. 
Bergamasco, A., Zago, C., 1999. Exploring the nitrogen cycle and macroalgae dynamics in the Lagoon of Venice using a multibox model. Estuarine, Coastal and Shelf Science 48 (2), 155-175.

Beusen, A.H., Bouwman, A.F., Van Beek, L.P., Mogollón, J.M., Middelburg, J.J., 2016. Global riverine $\mathrm{N}$ and $\mathrm{P}$ transport to ocean increased during the 20th century despite increased retention along the aquatic continuum. Biogeosciences 13 (8), 2441.

Billen, G., Lancelot, C., Meybeck M., 1991. N, P and Si retention along the aquatic continuum from land to ocean. In: Mantoura RFC, Martin JM, Wollast R. (Eds.), Ocean Margin Processes in Global Change. Dahlem Workshop Reports. Wiley, pp. 19-44.

Bishop, K., Buffam, I., Erlandsson, M., Folster, J., Laudon, H., Seibert, J., Temnerud, J., 2008. Aqua Incognita: the unknown headwaters. Hydrological Processes 22 (8), 1239-1242.

Blomqvist, S., Gunnars, A., Elmgren, R., 2004. Why the limiting nutrient differs between temperate coastal seas and freshwater lakes: a matter of salt. Limnology and Oceanography 49 (6), 22362241.

Bourblanc, M., 2014. Framing environmental problems: problem entrepreneurs and the issue of water pollution from agriculture in Brittany, 1970-2005. Journal of Environmental Policy \& Planning 16 (1), 21-35.

Carpenter, S.R., Caraco, N.F., Correll, D.L., Howarth, R.W., Sharpley, A.N., Smith, V.H., 1998. Nonpoint pollution of surface waters with phosphorus and nitrogen. Ecological applications 8 (3), 559-568.

Carpenter, S. R., Ludwig, D., \& Brock, W. A.,1999. Management of eutrophication for lakes subject to potentially irreversible change. Ecological applications, 9 (3), 751-771.

Carpenter, S.R., Lathrop, R.C., Nowak, P., Bennett, E.M., Reed, T., Soranno, P.A., 2006. The ongoing experiment: restoration of Lake Mendota and its watershed. In : Long-term Dynamics of Lakes in the Landscape (J.J. Magnusson, T.K. Kratz, B.J. Benson, eds), Oxford University Press, London 236-256.

Cellina, F., De Leo, G.A., Rizzoli, A.E., Viaroli, P., Bartoli, M., 2003. Economic modelling as a tool to support macroalgal bloom management: a case study (Sacca di Goro, Po river delta). Oceanologica Acta 26 (1), 139-147. 
Chapelle, A., Ménesguen, A., Deslous-Paoli, J.-M., Souchu, P., Mazouni, N., Vaquer, A., Millet, B., 2000. Modelling nitrogen, primary production and oxygen in a Mediterranean lagoon. Impact of oysters farming and inputs from the watershed. Ecological modelling 127 (2), 161-181.

Chen, D., Hu, M., Guo, Y., Dahlgren, R.A., 2016. Modelling forest/agricultural and residential nitrogen budgets and riverine export dynamics in catchments with contrasting anthropogenic impacts in eastern China between 1980-2010. Agriculture, Ecosystems \& Environment 221, 145 155.

Claussen, U., Zevenboom, W., Brockmann, U., Topcu, D., Bot, P., 2009. Assessment of the eutrophication status of transitional, coastal and marine waters within OSPAR. Hydrobiologia 629 (1), 49-58.

Conley, D.J., 1999. Biogeochemical nutrient cycles and nutrient management strategies. Man and River Systems. Springer pp 87-96.

Conley, D.J., Paerl, H.W., Howarth, R.W., Boesch, D.F., Seitzinger, S.P., Havens, K.E., Lancelot, C., Likens, G.E., 2009a. Controlling eutrophication: nitrogen and phosphorus. Science 323 (5917), 1014-1015.

Conley, D.J., Paerl, H.W., Howarth, R.W., Boesch, D.F., Seitzinger, S.P., Havens, K.E., Lancelot, C., Likens, G.E., 2009b. Eutrophication: Time to Adjust Expectations Response. Science 324 (5928), 724-725.

Cugier, P., Billen, G., Guillaud, J., Garnier, J., Ménesguen, A., 2005. Modelling the eutrophication of the Seine Bight (France) under historical, present and future riverine nutrient loading. Journal of Hydrology 304 (1), 381-396.

de Jonge, V.N., Elliott, M., Orive, E., 2002. Causes, historical development, effects and future challenges of a common environmental problem: eutrophication. Hydrobiologia 475 (1), 1-19.

Diaz R.J., Rosenberg R., 2008. Spreading dead zones and consequences for marine ecosystems. Science 321 (5891), 926-929.

de Jong, F., 2016. Ecological knowledge and North Sea environmental policies. Environmental Science and Policy 55, 449-455. 
Delmas, M, Saby, N., Arrouays, D., Dupas, R., Lemercier, B., Pellerin, S., Gascuel-Odoux, C., 2013. Explaining and mapping total phosphorus content in French topsoils. Soil Use and Management 31, 259-269.

Dillon, P. J., \& Rigler, F. H., 1974. The phosphorus-chlorophyll relationship in lakes 1, 2. Limnology and oceanography $19(5), 767-773$.

Dodds, W.K., Bouska, W.W., Eitzmann, J.L., Pilger, T.J., Pitts, K.L, Riley, A.J., Schloesser, J.T.,and Thornbrugh, D.J., 2009. Eutrophication of US freshwaters: analysis of potential economic damages. 43 (1), 12-19.

Doney S.C., 2010. The Growing Human Footprint on Coastal and Open-Ocean Biogeochemistry. Science 328 (5985), 1512-1516.Duarte, C. M., Conley, D. J., Carstensen, J., \& Sánchez-Camacho, M., 2009. Return to Neverland: shifting baselines affect eutrophication restoration targets. Estuaries and Coasts 32 (1), 29-36.Dupas, R., Delmas, M., Dorioz, J.-M., Garnier, J., Moatar, F., Gascuel-Odoux, C., 2015. Assessing the impact of agricultural pressures on N and P loads and eutrophication risk. Ecological Indicators 48, 396-407.

Durand, P., Moreau, P., Salmon-Monviola, J., Ruiz, L., Vertes, F., Gascuel-Odoux, C., 2015. Modelling the interplay between nitrogen cycling processes and mitigation options in farming catchments. The Journal of Agricultural Science 153 (6), 959-974.

Elser, J.J., Bracken, M.E.S., Cleland, E.E., Gruner, D.S., Harpole, W.S., Hillebrand, H., Ngai, J.T., Seabloom, E.W., Shurin, J.B., Smith, J.E., 2007. Global analysis of nitrogen and phosphorus limitation of primary producers in freshwater, marine and terrestrial ecosystems. Ecology Letters $10(12), 1135-1142$.

Ferreira, J.G., Andersen, J.H., Borja, A., Bricker, S.B., Camp, J., Da Silva, M.C., Garces, E., Heiskanen, A.S., Humborg, C., Ignatiades, L., Lancelot, C., Ménesguen, A., Tett, P., Hoepffner, N., Claussen, U., 2011. Overview of eutrophication indicators to assess environmental status within the European Marine Strategy Framework Directive. Estuarine, Coastal and Shelf Science 93 (2), 117-131. 
Floury, M., Usseglio-Polatera, P., Delattre, C., Souchon, Y., 2017. Assessing long-term effects of multiple, potentially confounded drivers in ecosystems from species traits. Global Change Biology 23 (6), 2297-2307.

Folke, C., Kautsky, N., Troell, M., 1994. The Costs of Eutrophication from Salmon Farming: implications for Policy. Journal of Environmental Management 40, 173-182.Friberg, N., 2014. Impacts and indicators of change in lotic ecosystems. Wiley Interdisciplinary Reviews: Water 1 (6), 513-531.

Garnier, J., Lassaletta, L., Billen, G., Romero, E., Grizzetti, B., Némery, J., Le, T.P.Q., Pistocchi, C., Aissa-Grouz, N., Luu, T.N.M., 2015. Phosphorus budget in the water-agro-food system at nested scales in two contrasted regions of the world (ASEAN-8 and EU-27). Global Biogeochemical Cycles 29 (9), 1348-1368.

Gould, K.A., 1993. Pollution and perception: Social visibility and local environmental mobilization. Qualitative Sociology $16(2), 157-178$.

Gren, I.-M., Tore Söderqvist, T., Wulff, F., 1997. Nutrient Reductions to the Baltic Sea: Ecology, Costs and Benefits. Journal of Environmental Management 51, 123-143.Hansen, L.B., Hansen, L.G., 2014. Can Non-point Phosphorus Emissions from Agriculture be Regulated Efficiently Using Input-Output Taxes? Environmental and Resource Economics 58 (1), 109-125.

Hecky, R. E., \& Kilham, P., 1988. Nutrient limitation of phytoplankton in freshwater and marine environments: a review of recent evidence on the effects of enrichment 1. Limnology and Oceanography 33 (4 part 2), 796-822.

Howarth, R.W., 2008. Coastal nitrogen pollution: a review of sources and trends globally and regionally. Harmful algae 8 (1), 14-20.

Howarth, R.W., Marino, R., 2006. Nitrogen as the limiting nutrient for eutrophication in coastal marine ecosystems: Evolving views over three decades. Limnology and Oceanography 51 (1), 364376.

Ibisch, R., Austnes, K., Borchardt, D., Boteler, B., Leujak, W., Lukat, E., Rouillard, J., Schmedtje, U., Solheim, A.L., Westphal, K., 2017. European assessment of eutrophication abatement measures across land-based sources, inland, coastal and marine waters. European Topic Centre on Inland, 
Coastal and Marine Waters, Helmholtz Centre for Environmental Research GmbH-UFZ, Germany, ETC/ICM Technical Report - 2/2016, 95 p.

James, C., Fisher, J., Russell, V., Collings, S., \& Moss, B., 2005. Nitrate availability and hydrophyte species richness in shallow lakes. Freshwater biology 50 (6), 1049-1063.

Jarvie, H.P., Sharpley, A.N., Spears, B., Buda, A.R., May, L., Kleinman, P.J.A., 2013a. Water Quality Remediation Faces Unprecedented Challenges from "Legacy Phosphorus". Environmental Science \& Technology 47 (16), 8997-8998.

Jarvie, H.P., Sharpley, A.N., Withers, P.J., Scott, J.T., Haggard, B.E., Neal, C., 2013b. Phosphorus mitigation to control river eutrophication: Murky waters, inconvenient truths, and "post normal" science. Journal of Environmental Quality 42 (2), 295-304.

Jarvie, H.P., Johnson, L.T., Sharpley, A.N., Smith, D.R., Baker, D.B., Bruulsema, T.W., Confesor, R. 2017. Increase soluble phosphorus loads to Lake Erie: unintended consequences of conservation practices? Journal of Environmental Quality 46, 123-132.

Jarvie, H.P., Smith, D.R., Norton, L.R., Edwards, F.K, Bowes, M.J., King, S.M., Scarlett, P., Davies, S., Dils, R.M., Bachiller-Jareno, N., 2018. Phosphorus and nitrogen limitation and impairment of headwater streams relative to rivers in Great Britain: A national perspective on eutrophication. Science of the Total Environment 621, 849-862.

Jeppesen, E., Meerhoff, M., Davidson, T.A., Trolle, D., Sondergaar, D.M., Lauridsen, T.L., Beklioglu, M., Brucet Balmaña, S., Volta, P., González-Bergonzoni, I., 2014. Climate change impacts on lakes: an integrated ecological perspective based on a multi-faceted approach, with special focus on shallow lakes. Journal of Limnology 72 (s1), 84-107.

Jeppesen, E., Meerhoff, M., Davidson, T.A., Trolle, D., Sondergaard, M., Lauridsen, T.L., Beklioglu, M., Brucet Balmaña, S., Volta P., González-Bergonzoni I., 2014. Climate change impacts on lakes: an integrated ecological perspective based on a multi-faceted approach, with special focus on shallow lakes. Journal of Limnology 73 (s1), 84-107.

Jørgensen, S.E. and Bendoricchio, G., 2001. Fundamentals of ecological modelling (Vol. 21). Elsevier. Science: Amsterdam. 544 pages. ISBN: 9780080532103 
Jørgensen, S.E., 2010. A review of recent developments in lake modelling. Ecological modelling 221 (4), 689-692.

Kemp, W.M., Boynton, W.R., Adolf, J.E., Boesch, D.F., Boicourt, W.C., Brush, G., Cornwell, J.C., Fisher, T.R., Glibert, P.M., Hagy, J.D., 2005. Eutrophication of Chesapeake Bay: historical trends and ecological interactions. Marine Ecology Progress Series 303, 1-29.

Kemp, W.M., Testa, J.M., Conley, D.J., Gilbert, D., Hagy, J.D., 2009. Temporal responses of coastal hypoxia to nutrient loading and physical controls. Biogeosciences 6 (12), 2985-3008.

Kolbe, T., Marçais, J., Thomas, Z., Abbott, B.W., de Dreuzy, J-R., Rousseau-Gueutin, P., Aquilina, L., Labasque, T., Pinay, G., 2016. Coupling 3D groundwater modeling with CFC-based age dating to classify local groundwater circulation in an unconfined crystalline aquifer. Journal of Hydrology doi: http:// dx.doi.org/10.1016/j.jhydrol.2016.05.020.

Laukkanen, M., Huhtala, A., 2008. Optimal management of a eutrophied coastal ecosystem: balancing agricultural and municipal abatement measures. Environmental and Resource Economics 39 (2), 139-159.

Levain, A., Vertès, F., Ruiz, L., Delaby, L., Gascuel-Odoux, C., Barbier, M., 2015. 'I am an Intensive Guy': The Possibility and Conditions of Reconciliation Through the Ecological Intensification Framework. Environmental Management 56 (5), 1184-1198.

Lu, C., Tian, H., 2017. Global nitrogen and phosphorus fertilizer use for agriculture production in the past half century: shifted hot spots and nutrient imbalance. Earth System Science Data 9 (1), 181.

Moatar, F., Meybeck, M., 2005. Compared performances of different algorithms for estimating annual nutrient loads discharged by the eutrophic River Loire. Hydrological Processes: An International Journal 19(2), 429-444.

Molenat, J., Gascuel-odoux, C., Aquilina, L., Ruiz, L., 2013. Use of gaseous tracers (CFCs and $\left.\mathrm{SF}_{6}\right)$ and transit-time distribution spectrum to validate a shallow groundwater transport model. Journal of Hydrology 480, 1-9.

Minaudo, C., Meybeck, M., Moatar, F., Gassama, N., Curie, F., 2015. Eutrophication mitigation in rivers: 30 years of trends in spatial and seasonal patterns of biogeochemistry of the Loire River (1980-2012). Biogeosciences 12 (8), 2549-2563. 
Moss, B., Kosten, S., Meerhoff, M., Battarbee, R.W., Jeppesen, E., Mazzeo, N., Havens, K., Lacerot, G., Liu, Z., De Meester, L., 2011. Allied attack: climate change and eutrophication. Inland Waters $1(2), 101-105$.

MSFD,2008. Directive 2008/56/EC of the European Parliament and of the Council of 17 June 2008 establishing a framework for community action in the field of marine environmental policy (Marine Strategy Framework Directive) (Text with EEA relevance).

MSFD,2017. Rectificatif à la décision (UE) 2017/848 de la Commission du 17 mai 2017 établissant des critères et des normes méthodologiques applicables au bon état écologique des eaux marines ainsi que des spécifications et des méthodes normalisées de surveillance et d'évaluation, et abrogeant la directive 2010/477/UE (JO L 125 du 18.5.2017).

Paerl, H.W., 2009. Controlling eutrophication along the freshwater-marine continuum: dual nutrient $(\mathrm{N}$ and $\mathrm{P})$ reductions are eessential. Estuaries and Coasts $32(4), 593-601$.

Paerl, H.W, 2018. Mitigating toxic planktonic cyanobacterial blooms in aquatic ecosystems facing increasing anthropogenic and climatic pressures. Toxins 10, 76.

Paerl, H.W., Scott, J.T., McCarthy, M.J., Newell, S.E., Gardner, W.S., Havens, K.E., Hoffman, D.K., Wilhelm, S.W., Wurtsbaugh, W.A., 2016. It Takes Two to Tango: When and Where Dual Nutrient (N \& P) Reductions Are Needed to Protect Lakes and Downstream Ecosystems. Environmental Science \& Technology 50 (20), 10805-10813.

Paerl, H.W., Hall, N.S., Peierls, B.L., Rossignol, K.L., 2014. Evolving paradigms and challenges in estuarine and coastal eutrophication dynamics in a culturally and climatically stressed world. Estuaries and Coasts 37 (2), 243-258.

Pahl-Wostl, C., 2007. Transitions towards adaptive management of water facing climate and global change. Water Resources Management 21 (1), 49-62.

Pahl-Wostl, C., 2007. Transitions towards adaptive management of water facing climate and global change. Water Resources Management, 21 (1), 49-62.

Paolisso, M., 1999. Toxic Algal Blooms, Nutrient Runoff, and Farming on Maryland's Eastern Shore. Culture \& Agriculture 21(3), 53-58. 
Pinay G., Peiffer, S., De Dreuzy, J.R., Krause, S., Hannah, D.M., Fleckenstein, J.H., Sebilo, M., Bishop, K., Hubert-Moy, L., 2015. Upscaling nitrogen removal capacity from hot spot to the landscape. Ecosystems 18 (6): 1101-1120.

Rabalais, N.N., Turner, R.E., Scavia, D., 2002. Beyond Science into Policy: Gulf of Mexico Hypoxia and the Mississippi River. Bioscience 52 (2), 129-142.

Rabalais, N.N., 2004. Eutrophication. The global coastal ocean: multiscale interdisciplinary processes. In : The global coastal ocean: multiscale interdisciplinary processes (A.R. Robinson, K.H. Brink, eds., 2005), Harvard University Press.

Romo, S., Soria, J., Fernandez, F., Ouahid, Y., Baron-Sola A., 2013. Water residence time and the dynamics of toxic cyanobacteria. Freshwater Biology, 58 (3), 513-522.

Romstad, E., 2014. The Economics of Eutrophication. Eutrophication: Causes, Consequences and Control. Springer 45-53.

Scheffer, M., Carpenter, S., Foley, J. A., Folke, C., \& Walker, B. (2001). Catastrophic shifts in ecosystems. Nature 413 (6856), 591-596.

Schindler, D.W., 1974. Eutrophication and recovery in experimental lakes: implications for lake management. Science 184 (4139), 897-899.

Schindler, D.W., 2012. The dilemma of controlling cultural eutrophication of lakes. Proceedings of the Royal Society B-Biological Sciences 279 (1746), 4322-4333.

Schoumans, O., Chardon, W., Bechmann, M., Gascuel-Odoux, C., Hofman, G., Kronvang, B., Rubæk, G.H., Ulén, B., Dorioz, J.-M., 2014. Mitigation options to reduce phosphorus losses from the agricultural sector and improve surface water quality: a review. Science of the Total Environment $468,1255-1266$.

Sébilo, M., Mariotti, A., Mayer, B., Pinay G., 2013. Long term release of nitrate from agricultural plant-soil system. Proceeding of the National Academy of Science 110 (45), 18185-18189.

Skogen, M.D., Eilola, K., Hansen, J.L., Meier, H.M., Molchanov, M.S., Ryabchenko, V.A., 2014. Eutrophication status of the North Sea, Skagerrak, Kattegat and the Baltic Sea in present and future climates: A model study. Journal of Marine Systems 132, 174-184. 
Smetacek, V., Zingone, A., 2013. Green and golden seaweed tides on the rise. Nature 504 (7478), 8488.

Smith, D.R., King, K.W., Williams, M.R., 2015. What is causing the harmful algal blooms in Lake Erie? J. Soil Water Conservation 70: 27A-29A. doi:10.2489/jswc.70.2.27A.

Smith, V.H., 2003. Eutrophication of freshwater and coastal marine ecosystems a global problem. Environmental Science and Pollution Research 10 (2), 126-139.

Smith, V.H., Schindler, D.W., 2009. Eutrophication science: where do we go from here? Trends in Ecology \& Evolution 24 (4), 201-207.

Smith, V.H., Tilman, G.D., Nekola, J.C., 1999. Eutrophication: impacts of excess nutrient inputs on freshwater, marine, and terrestrial ecosystems. Environmental Pollution 100 (1), 179-196.

Smith, V.H., Tilman, G.D., Nekola, J.C., 1999. Eutrophication: impacts of excess nutrient inputs on freshwater, marine, and terrestrial ecosystems. Environmental Pollution 100 (1), 179-196.

Sutton, M.A., Howard, C.M., Erisman, J.W., Billen, G., Bleeker, A., Grennfelt, P., Van Grinsven, H., Grizzetti, B., 2011. The European nitrogen assessment: sources, effects and policy perspectives. Cambridge University Press.

Thornton, J.A., Harding, W.R., Dent, M., Hart, R.C., Lin, H., Rast, C.L., Rast, W., Ryding, S.O., Slawski, T.M., 2013. Eutrophication as a ‘wicked’problem. Lakes \& Reservoirs: Research \& Management 18 (4), 298-316.

Troost, T., Blaas, M., Los, F., 2013. The role of atmospheric deposition in the eutrophication of the North Sea: a model analysis. Journal of Marine Systems 125, 101-112.

Turner, R., Rabalais, N., Justic, D., 2006. Predicting summer hypoxia in the northern Gulf of Mexico: Riverine N, P, and Si loading. Marine pollution bulletin 52 (2), 139-148.

Udovyk, O., Gilek, M., 2013. Coping with uncertainties in science-based advice informing environmental management of the Baltic Sea. Environmental Science \& Policy 29, 12-23.

Visser, P. M., Ibelings, B. W., Bormans, M., \& Huisman, J., 2016. Artificial mixing to control cyanobacterial blooms: a review. Aquatic Ecology 50 (3), 423-441. 
Vitousek, P.M., Aber, J.D., Howarth, R.W., Likens, G.E., Matson, P.A., Schindler, D.W., Schlesinger, W.H., Tilman, D.G., 1997. Human alteration of the global nitrogen cycle: sources and consequences. Ecological Applications 7 (3), 737-750.

Vollenweider, R. A., 1968. Scientific fundamentals of the eutrophication of lakes and flowing waters, with particular reference to nitrogen and phosphorus as factors in eutrophication. Paris (France) Organisation for Economic Co-operation and Development, OECD Technical Report DAS/CSI/68.27.

Von Blottnitz, H., Rabl, A., Boiadjiev, D., Taylor, T., Arnold, S., 2006. Damage costs of nitrogen fertilizer in Europe and their internalization. Journal of Environmental Planning and Management $49(3), 413-433$.

WFD, 2000. Directive 2000/60/EC of the European Parliament and of the Council of 23 October 2000 establishing a framework for Community action in the field of water policy.Withers, P.J., Neal, C., Jarvie, H.P., Doody, D.G., 2014. Agriculture and eutrophication: where do we go from here?

Sustainability 6 (9), 5853-5875.

Withers, P.J.A., Jarvie, H.P., 2008. Delivery and cycling of phosphorus in rivers: A review. Science of the Total Environment 400 (1-3), 379-395.

Woznicki, S.A., Nejadhashemi, A.P., Tang, Y., Wang, L., 2016. Large-scale climate change vulnerability assessment of stream health. Ecological Indicators 69, 578-594.

Xepapadeas, A., 2011. The economics of non-point-source pollution. Annual Rev. Resour. Econ. 3 (1), 355-373.

Zamparas, M., Zacharias, I., 2014. Restoration of eutrophic freshwater by managing internal nutrient loads. A review. Science of the Total Environment 496, 551-562. 


\section{Figures \& Table caption}

772 Figure 1. Changes in physico-chemical parameters and in the relative dominance of plants and

773 biodiversity depending on the degree of eutrophication in an aquatic environment. Although marine

774 and freshwater systems do not host the same species, the succession of plant functional types is

775 similar. Schematically, benthic macrophytes capable of tapping nutrients from sediment dominate in

776 nutrient-poor environments. When the environment is enriched, epiphytes, followed by emerging

777 macrophytes, opportunistic floating macrophytes and/or phytoplankton proliferate at the expense of

778 perennial and submerged macrophytes, which no longer have access to light. ${ }^{\mathrm{ED}}$ : observable in

779 freshwater only.

780

781 Figure 2. Conceptual diagram of the transfer, retention and removal zones of nitrogen and phosphorus 782 along the land-sea continuum.

Figure 3. Schematic representation of six hypothetical system response trajectories (in y) following changes in nutrient conditions (in $\mathrm{x}$ ). Hysteresis refers to the fact that two different status of an ecosystem can be found along an intermediate gradient of nutrient concentrations. Source: Kemp et al. (2009).

Table 1. Pressure, status and impact indicators of eutrophication in rivers, lakes, transitional waters, coastal and marine waters. * only for stratified lakes. Adapted from Ibisch et al. (2017). 


\begin{tabular}{|c|c|c|c|c|c|}
\hline Indicators & Rivers & Lakes & $\begin{array}{l}\text { Transitional } \\
\text { waters }\end{array}$ & $\begin{array}{l}\text { Coastal } \\
\text { water }\end{array}$ & $\begin{array}{l}\text { Ocean } \\
\text { water }\end{array}$ \\
\hline \multicolumn{6}{|l|}{ Pressure indicators } \\
\hline $\begin{array}{l}\text { Nutrient emissions, nutrient load } \\
\text { Status indicators }\end{array}$ & $\mathrm{x}$ & $\mathrm{x}$ & $\mathrm{x}$ & $\mathrm{x}$ & $\mathrm{x}$ \\
\hline Phosphorus concentrations (total P, ortho-phosphate) & $\mathrm{x}$ & $\mathrm{x}$ & $\mathrm{x}$ & $\mathrm{x}$ & $\mathrm{X}$ \\
\hline $\begin{array}{l}\text { Nitrogen concentrations (total N, NO3) } \\
\text { Impact indicators }\end{array}$ & $\mathrm{x}$ & $\mathrm{x}$ & $\mathrm{x}$ & $\mathrm{x}$ & $\mathrm{x}$ \\
\hline $\begin{array}{l}\text { Ecological status (WFD: European Water Framework } \\
\text { Directive) }\end{array}$ & $\mathrm{x}$ & $\mathrm{x}$ & $\mathrm{x}$ & $\mathrm{x}$ & \\
\hline $\begin{array}{l}\text { Environmental status (MSFD: Marine Strategy Framework } \\
\text { Directive) }\end{array}$ & & & & $\mathrm{x}$ & $\mathrm{x}$ \\
\hline Phytoplankton (chl-a, biovolume) & $\mathrm{x}$ & $\mathrm{x}$ & $\mathrm{X}$ & $\mathrm{x}$ & $\mathrm{x}$ \\
\hline $\begin{array}{l}\text { Phytoplankton (community composition, harmful and toxic } \\
\text { algae) }\end{array}$ & & $\mathrm{x}$ & & $\mathrm{x}$ & $\mathrm{x}$ \\
\hline Secchi depth & & $\mathrm{x}$ & & $\mathrm{x}$ & $\mathrm{x}$ \\
\hline Macrophytes (depth of lower growth) & & $\mathrm{x}$ & & $\mathrm{x}$ & \\
\hline Macrophytes (community composition) & $\mathrm{x}$ & $\mathrm{x}$ & $\mathrm{x}$ & $\mathrm{x}$ & \\
\hline Phytobenthos (community composition of benthic algae) & $\mathrm{x}$ & $\mathrm{x}$ & & & \\
\hline Macrozoobenthos (community composition, biomass) & $\mathrm{x}$ & $\mathrm{x}$ & $\mathrm{x}$ & $\mathrm{x}$ & $\mathrm{x}$ \\
\hline Oxygen concentration at the bottom & & $\mathrm{X}^{*}$ & $\mathrm{X}$ & $\mathrm{x}$ & $\mathrm{X}$ \\
\hline
\end{tabular}


Figure 1 : Le Moal et al.

797

798

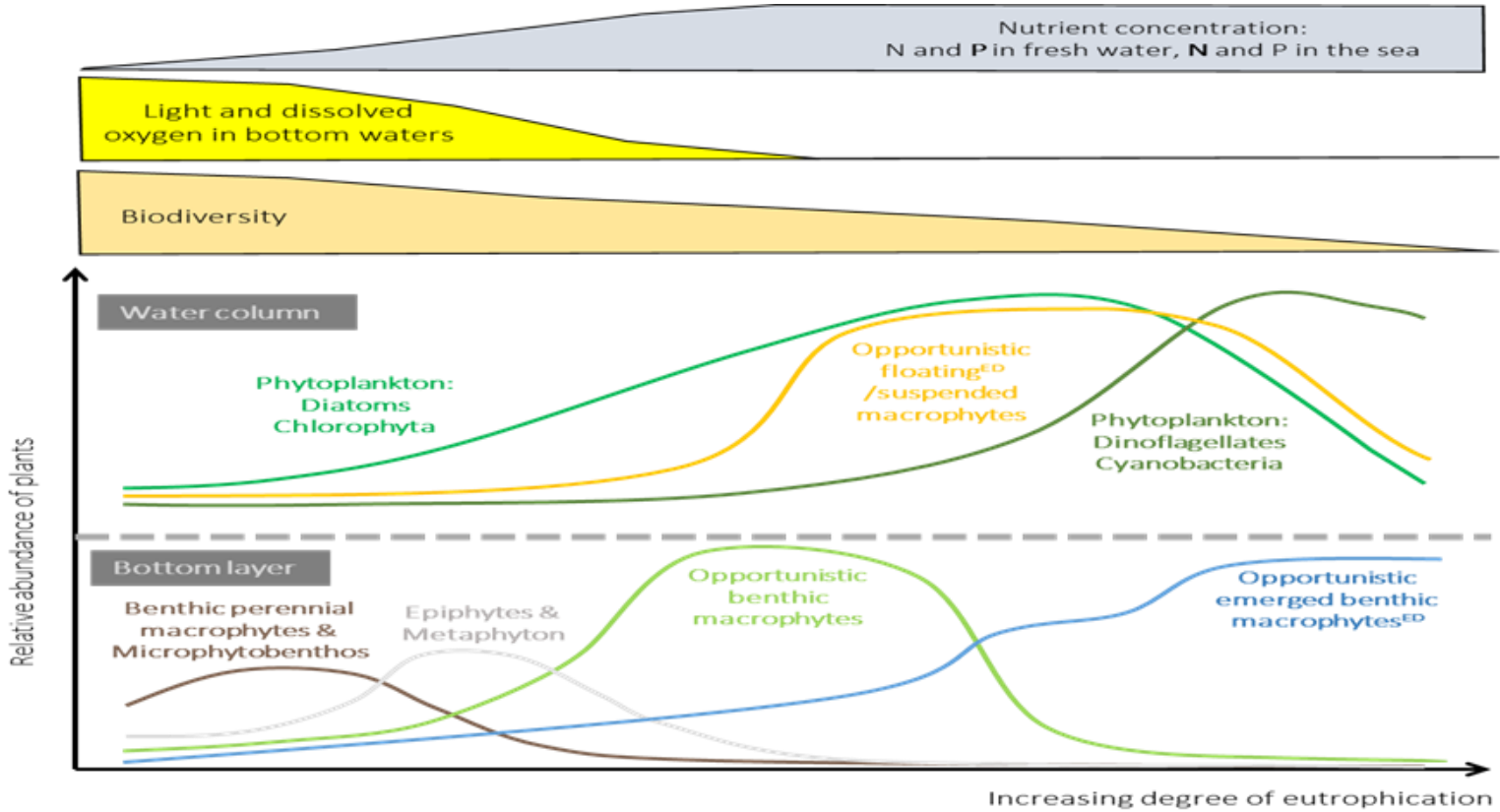

799

increasing degree of eutrophication

800

801 


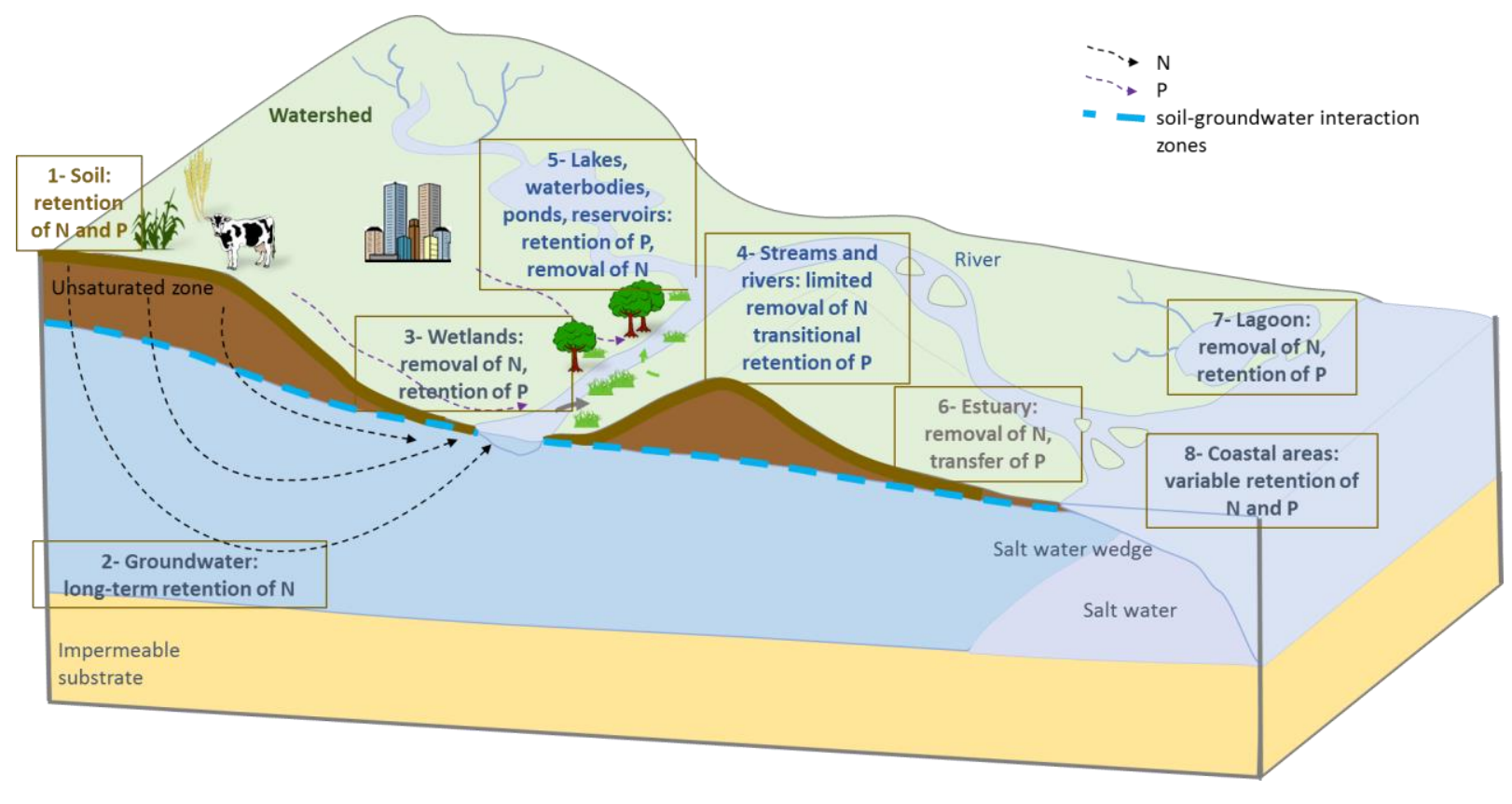


Figure 3 : Le Moal et al.

807

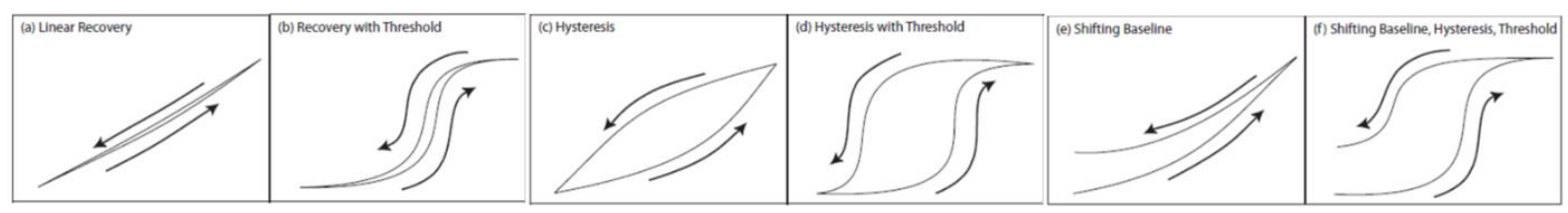

